\title{
THE UNITED STATES IN VIETNAM: A CASE STUDY IN THE LAW OF INTERVENTION
}

\section{INTRODUCTION}

Vietnam is presently the site of armed conflict between guerrillas and the Diem government. It is clear that the guerrillas have the support of North Vietnam, and that the United States supports Diem. The East-West controversy over Vietnam has brought forth charges by each side that the other has been breaching promises made at Geneva in 1954 and otherwise violating international law. ${ }^{1}$ Although the charges undoubtedly have been motivated in part by desires to make propaganda gains, they have some foundation in law and fact, and they merit objective analysis. While the facts perhaps cannot be fully known by reading only Western pnblications, one can try to inake a legal analysis of the facts available from Western sources in order to see whether the United States is respecting international law in Vietnam.

To determine the legal situation in Vietnam, three questions must be answered:

$(A)$ Is there a dispute endangering international peace or security?

$(B)$ Does the coercive opposition to Diem come solely from subversive intervention by North Vietnam, is the conflict in Vietnam solely internal, or is Diem confronted with a combination of internal insurgency and North Vietnamese subversive intervention?

(C) What is the nature of United States support for the Diem government?

A.

The position of the United States as to whether there is a dispute endangering international peace or security is ambivalent. On the one hand, Secretary of State Rusk has labelled the Viet Cong activities "a threat to the peace,"2 and has said that "the stakes are greater than South Viet-Nam itself." ${ }^{3}$ These statements are in accord with the United States Declaration on Indo-China made at the close of the 1954 Geneva Conference: "[The United States] would view any renewal of the aggression in violation of the aforesaid agreements with grave concern and as seriously threatening international peace and security." 4 The State Department says that "the present balance of forces between independent and Communist states in Asia would be tipped perilously if Viet-Nam, Cambodia, and Laos fell under Communist domination. What then would be the prospects for Thailand and Burma, for Pakistan and India, for Malaya and Indonesia?"5 One might easily

1 "There is no question that the North Vietnamese have been systematically violating the 1954 Geneva Accords." Secretary of State Rusk's Press Conference of Dec. 8, 1961, in 45 DeP'T State BuLL. 1058 (1961). "[T] Ue United States . . flagrantly violates the Geneva agreements of 1954 on Vietnam and creates a serious threat to the peace in that region." Statement of the Soviet Foreign Ministry, March 17, 1962, N.Y.Times, March 18, 1962, p.30, col.1.

2 Press Conference of Nov. 17, 1961, in 45 DEP'T State Bulx. 920 (1961).

3 Address by Secretary of State Rusk, Davidson College, Feb. 22, 1962, in 46 DeP'T State BuLt. 450 (1962).

431 Dep't State Buld. 162 (1954).

- Departalent of State, far Eastern Sertes 110, A Threat to the Peace, North VIET-NAM's EFForT to Conguer SOUTH VIET-NAM, pt. I, 52 (1961) [heremafter cited as A Threat to the Peace]. 
infer that the United States believes the current situation in Vietnam poses a threat to international peace and security. But there are indications to the contrary. Secretary Rusk has said that he would not at present take the question of Vietnam to the United Nations, ${ }^{6}$ implying that the Vietnamese conflict is not a dispute or situation endangering international peace and security within the meaning of Article 33 of the United Nations Charter. The New York Times reports that United States officials discount "the danger of early involvement or foreign Communist and United States troops in direct combat. ..."T These apparent contradictions in American statements are probably caused by a desire on the one hand to reassure South Vietnam and build up American and world sentiment against the North Vietnamese, and the conflicting desire to justify keeping the Vietnamese question out of the United Nations. ${ }^{8}$ It should finally be noted that the Soviet Union, ${ }^{0}$ Communist China, and, according to the New York Times, "some Western allies," 10 all claim the dispute is dangerous.

$B$.

It does not appear that the sole source of the Diem government's trouble is Vietminh intervention. President Kennedy impliedly recognized that some of the guerrilla forces were Vietnamese when he said: "There has been evidence that some of these forces have come from beyond the borders." 11 A Rand Corporation researcher found that whole areas of the country were not only friendly to the Communists, but were actively hostile to the Diem regime..$^{12}$ Vietnamese intelligence reports say that twenty per cent of the villagers of the nation favor the Viet Cong. ${ }^{13}$ Thus, we must credit the conclusion that Vietnam is engaged in "a political and social revolution which, for all of the outside Communist interference, has deep, indigenous, popular roots." 14

Equally inevitable is the conclusion that the Vietnamese conflict is not solely an internal struggle. Hanoi radio can be heard beaming subversive propaganda into Vietnam. ${ }^{15}$ The Hanoi press prints and disperses subversive pamphlets. ${ }^{10}$

6 Secretary of State Rusk's Press Conference of Dec. 8, 1961, in 44 DEP'T State BuLL. 1058 (1961).

7 N.Y. Times, April 28, 1962, p. 1, col. 8.

8 The statements cannot be explained away as mere off-the-cuff remarks. The State Department is aware of the scrutiny given its statements and is accordingly careful and reflective in making them. Then-Acting Secretary of State Ball has made this quite clear: "No responsible officer of the Department of State can make a public statement about world affairs without being aware that he is speaking to more than one audience. Whatever he says to Americans regarding the thrust and purpose of any aspect of foreign policy will be meticulously studied in the chanceries of the world." Address by Acting Secretary of State Ball to the Northwestern Law Alumni Ass'n, May 9, 1962, in 46 DEP'T STATE BuIx. 872, 873 (1961).

${ }^{9}$ In a story dated Feb. 27, 1962, the N.Y. Times said: "The Soviet Union warned today that United States military action against Communist guerrillas in South Vietnam involved a possibility of 'alarming consequences' for world peace." N.X. Times, Feb. 28, 1962, p. 1, col. 8. The Soviet Foreign Ministry bas said the American action "creates a serious threat to the peace in that region." N.Y. Times, March 18, 1962, p. 30, col.1.

10N.Y. Times, April 28, 1962, p. 1, col. 8.

11 President Kennedy's Press Conference of Oct. 11, 1961, in 19 Covo. Quar. 1742 (1961). (Emphasis added.)

12 TanhaM, Comarunist Revoluttonary Warfare 111 (1961).

13 Newsweek, April 30, 1962, p. 43.

14 Clubh, Trap in Vietnam, The Progressive, April 1962, p. 16. See also A Threat to the PEACE, pt. I, 7-11.

I5 A Tereat to the PeAce, pt. I, 17; TanhaM, op. cit. sufpra note 12, at 152.

16 See, e.g., Quang LoI, South of THE 17Th Parallex (Hanoi 1959). 
North Vietnamese come into Vietnam across the 17 th parallel, through Laos, and by sea. ${ }^{17}$ Once there they train and organize the guerrilla forces and eugage in terrorist activities and overt battle. ${ }^{18} \mathrm{~A}$ steady stream of supplies for the Viet Cong flows over the same routes. ${ }^{19}$

It thus appears that the Diem government is being subverted both from within and without. Viewed on the spectrnm of possible degrees of outside interference, the situation is, at the very least, like that described by Professor Wright: Vietnam "is the victim of hostilities, apparently domestic but actually incited and supported by propaganda, gun-running, infiltration of persons, or other activity from outside its territory, characterized as subversive intervention or 'indirect aggression. " 20 At most Vietnam is the victim of armed attack from outside supported by a large number of its own citizens.

\section{C.}

The United States, at the invitation of the Diem government, ${ }^{21}$ lias assumed an active role in the Vietnam conflict. Internationally it is exerting pressure on the International Control Commission, ${ }^{22}$ and consulting with other governments. ${ }^{23}$ SEATO, of which the United States is a nember, has taken a firm stand in favor of the present government, ${ }^{24}$ as has ANZUS. ${ }^{25}$ United States action within Vietnam is also far-reaching. President Kennedy has committed the United States to support the Diem government. ${ }^{26}$ Support has taken the form of economic, tech-

17 A Threat to the Peace, pt. I, 25.

18 Id. at 7-10, 12-13, 50. The Vietminh have followed "the pattern of, first, political organization, second, guerrilla warfare and, finally, frontal assault." Lindsay, Unconventional Warfare, 40 ForEIGN AFFAIRs 264, 267 (1962). Lindsay believes "the war for South Viet Nam has entered the third, or final, assault stage." The International Commission for Supervision and Control in Vietnam (commonly referred to as the International Control Commission), in its report of June 2, 1962, endorsed the finding of its legal committee (over Polish dissent) that: in specific mstances there is evidence to show that armed and unarmed personnel, arms, munitions and other supplies have been sent from the zone in the north (North Vietnam) to the zone in the south (South Vietnam) with the object of supporting, organizing, and carrrymg out hostile activities, including armed attacks, directed against the armed forces and administration of the zone in the south.

London Tines, June 26, 1962, p. 10, col.4. See US. Comment on Report of Control Commission for Viet-Nam, 14 DEP'T STATE BULL. 109 (1962).

19 A Threat to the Peace, pt. I, 32-37.

20 Wright, United States Intervention in the Lebanon, 53 Ax. J. INr'x L. 112, 122-23 (1959).

21 See Letter from President Diem to President Kennedy, Dec. 7, 1961, in 46 Dep't State BuLL. 13 (1962).

22 N.Y. Tines, April 28, 1962, p. 8, col. 3.

23 Secretary of State Rusk's Press Conference of Nov. 17, 1961, in 45 DEP'r STaTe BuLI. 922 (1961).

24 In a meeting of the SEATO Council of Ministers, March 27-29, a resolution was passed saying "The Council also noted with concern the efforts of an armed ninority, again supported froun outside in violation of the Geneva Accords, to destroy the Government of South VietNam, and declared its firm resolve not to acquiesce in any sucl take-over of that country." 44 Dep'r State Bull, 549 (1961).

25 N.Y. TMass, May 10, 1962, p. 6, col. 3.

20 Letter from President Kennedy to President Diem, Dec. 14, 1961, in 46 DEP'r Srate Burr. 13 (1962). The extent of the American commitunent to the Diem regime is further illustrated by the American Ambassador's attempt to influence Vietnamese politics. In a speech to the Saigon Rotarians he said that "social, economic and political reforms in South Vietnam could be accomplished quickly if the Vietnamese stopped criticizing their Governunent and tried to improve it from within." N.Y. Times, Feb. 16, 1962, p.1, col. 4. 
nical, and increasingly, military assistance. ${ }^{27}$ United States troops in Vietnam are training the Diem army, helping to plan strategy, participating in surveillance flights, and flying Vietnanese soldiers into combat. ${ }^{28}$ The stated American objective is "to assist this Government of South Viet-Nam and its armed forces to deal with this problem themselves, to win their own war against these guerrillas." 20 While American troops are not supposed to engage in combat, they "lave been instructed that if they are fired upon, they are of course to fire back, to protect themselves . . ." ${ }^{30}$ Thus, Americans have been killed by the Viet Cong, ${ }^{31}$ and wounded American soldiers are to receive the Purple Heart. ${ }^{32}$ Attorney General Kennedy has said that the United States is involved in "a struggle short of war."33 The Soviet Union has characterized this United States involvement as aggression. ${ }^{34}$

\section{II}

Having looked at the facts, we may now turn to the legal situation. Preliminary to an analysis of the United States position under general international law and the United Nations Charter, the question whether the United States is bound by the 1954 Geneva Accords on Indo-China should be briefly considered. These agreements ended the war in Indo-China. As to Vietnam, they drew a supposedly temporary armistice line, provided for later nation-wide elections, and contained detailed provisions governing the truce. An International Control Commission, composed of India, Poland, and Canada, was established to police the Accords.

$A$.

The United States appears not to be bound by the Geneva Accords. In agreeing to participate in the Geneva Conference of 1954, the United States did not commit itself to reach an agreement as to the situation in Indo-China. ${ }^{35}$ The Geneva Accords that resulted from the Conference consisted of two categories. First, there were armistice agreements between the opposing sides. In the case of

27 See President Kennedy's Press Conference of Feb. 14, 1962, in 20 Cong. QuAr. 266 (1962). The precise extent of American military involvement cannot be ascertained. As one newsman says, "[F]eelings on the Viet Namese Government side, the presence of the International Control Commission, and the desire to keep the American involvement image in low key probably contribute to the haze of secrecy that surrounds and cloaks Amercian operations here." Christian Science Monitor, June 27, 1962, p.4, col. 7 (Western ed.). The New York Times correspondent in Vietnam has charged that United States officials "don't want us to write anything which would make Congress and the American public exicted. We have to keep up the fiction that this isn't our war." Newsweek, July 2, 1962, p. 74.

28 Newsweek, April 30, 1962, pp. 36-45.

29 Interview with Secretary of State Rusk on "Washington Viewpoint," Feb. 12, 1962, in 46 Dep't StATE BuLI. 363 (1962).

30 President Kennedy's Press Conference, Feb. 14, 1962, in 20 Conc. Quar. 266 (1962).

31 N.Y. Times, June 17,1962 , p. 1, col. 2.

32 N.Y. Times, April 25, 1962, p. 1, ccl. 3.

33 This was said at a press conference in Saigon. The full interchange is interesting:

"Asked whether the United States was involved in a 'war' here, Mr. Kennedy asserted:

'We are involved in a struggle.'

"'What is the semantics of war and struggle?' he was asked.

"'It is a legal difference,' explained the Attorney General. 'Perhaps it adds up to the same thing. It is a struggle short of war." N.Y. Times, Feb. 19, 1962, p. 1, col. 5.

34 See N.Y. Times, Feb. 28, 1962, p.1, col.8; March 18, 1962, p. 30, col.1.

35 The quadripartite communique calling the conference merely stated tbat "the problem of restoring peace in Indochina will also be discussed. . ." 30 DEP'T STATE BuLl. 318 (1954). 
Vietnam the agreement was between representatives of the French fighting forces and of the Vietminh. Second, there was a final declaration of the Geneva Conference. As the Diem government has pointed out, "neither Viet-Nam nor the U.S. took part in drafting the final declaration nor did they approve it."36 Since the United States was not obligated to become a party to the Accords and did not become a party, it hardly seems arguable that it is bound by them. ${ }^{37}$ It has even been argued that since no member of the Conference signed the declaration, it binds no one, but is merely a declaration of intent. ${ }^{38}$

The United States, in its unilateral Declaration on Indo-China, has made clear its position with regard to the Accords:

(i) it will refrain from the threat or the use of force to disturb them, in accordance with Article 2(4) of the Cliarter of the United Nations dealing with the obligation of members to refrain in their international relations from the threat or use of force; and (ii) it would view any renewal of the aggression in violation of the aforesaid agreements with grave concern and as seriously threatening international peace and security. 39

By restating adherence to the charter and by warning against renewal of aggression the United States cannot be said to have become a party to the Accords. The unilateral declaration of the United States does not constitute a binding obligation. ${ }^{40}$ Those who have stated ${ }^{41}$ or implied ${ }^{42}$ that the Accords and unilateral declaration bind the United States have offered no legal reasons to support their position. Their only possible support comes from the United States denunciations of Communist violations of the Accords. ${ }^{43}$ It might be argued that by relying on the Accords the United States has obligated itself to observe them. But it would be anomalous to say that a nonsignatory state must observe an agreement merely because it has protested against violations of the agreement by a signatory. There appear to be no rules of international law leading to such a result, and a contrary result is indicated by the rule that the violation of essential provisions of an agreement creates a right for the other party to cancel the agreement. ${ }^{44}$

$B$.

Leaving aside the United Nations Charter for the moment, it appears that United States action in Vietnam is, under general international law, legal. While intervention in the affairs of another state is illegal under international law, the

36 Ministrx of Information, The Problem of Reunification of Viet-Nam 18 (Republic of Vietnam 1958).

37 See 1 OpPEnaEn, INTERNaTionat LAw 873 (8th ed. Lauterpacht 1955) [hereinafter cited as 1 OpPENHETar]; Ross, A TeXt-Book of InTERNaTtonal Law 218 (1947).

38 MrNISTRX of INFORMLATION, op. cit. supre note 36 , at 18 . This position finds some support in 1 OPPENEREM 873.

39 United States Declaration on Indochina, 31 Dep'r State Butr. 162 (1954).

40 See 1 OPPENHEER 873.

11 Clubb, Trap in Vietnam, The Progressive, April 1962, p.17; Statement of Soviet Foreign Ministry, in N.Y. Times, March 18, 1962, p. 30, col.1.

49 Wright, Intervention and Cuba in 1961, in 1961 Proceedngs AMERICAN Soc'x INT'x I. 2, 12 (1961): "The problem of subversion in the Congo should be left to the Unrited Nations, that in Laos and Viet Nam to the procedures set up by the Geneva Conference of 1954, and that in the Caribbean to the Organization of American States, all subject to the supervision of the United Nations."

43 See note 1 supra.

441 OPPENAETM 947. 
United States activity is justified because the Vietminh are illegally attempting to subvert Vietnam and because Vietnam has appealed to the United States for help.

The Vietminh activities described above unquestionably violate international law. First, they violate article 24 of the Geneva Agreement on Viet-Nam. Second, they violate the rule of general international law forbidding one state to intervene in the affairs of another. Third, they violate the United Nations Charter.

Article 24 of the Geneva Agreement on Viet-Nam provides in part:

The armed forces of each party shall respect the demilitarized zone and the territory under the military control of the other party, and shall commit no act and undertake no operation against the other party and shall not engage in blockade of any kind in Viet-Nam.45

The agreement was signed by North Vietnam and France, but not by South Nietnam. It therefore can be argued that South Vietnam acquired no rights under the agreement. ${ }^{46}$ The question of Vietnam's rights under the agreement is really irrelevant since, whether the Vietminh obligation is owed to Vietnam or not, there is a Vietminh obligation owed at least to France. By sending troops into Vietnam the Vietminh have violated article 24 of the agreement. 47

International law unequivocally forbids states to organize revolutionary, hostile expeditions into other states. ${ }^{48}$ There can be no doubt that the Vietminh have violated this universally accepted rule. ${ }^{49}$ States are also forbidden to allow their ter-

45 Agreement on the Cessation of Hostilities in Viet-Nam, July 20, 1954, GENEVA CoNP. Doc. No. IC/42/Rev. 2, in 1 AMrerican Foreign PoIICY: 1950-1955 Basic Documents 750, N.Y. Times, July 24,1954, p. 4.

46 See Ross, op. cit. supra note 37, at 217. Counter-arguments could be made that Vietnam became a party to the agreement via France's signing, that Vietnam is a third-party beneficiary, or that Vietnam became a party by impliedly acceding to the agreement. Each of these counterarguments, however, meets with difficulty. See Case of the Free Zones of Upper Savoy and the District of Gex, P.C.I.J., ser. A/B, No. 46 (1932), in 2 Hudson, Wortd Court REPorTs 508 (1935). The International Control Commission treats South Vietnam as a party to the agreement. In its report of June 2, 1962, it held that South Vietnam "has violated articles 16 and 17 of the Geneva agreement in receiving the increased military aid from the United States." London Times, June 26, 1962, p. 10, col. 4.

47 The International Control Commission, im its report of June 2, 1962, found (over Polish dissent) that North Vietnamese acts "are in violation of articles 10, 19, 24, and 27 of the agreement on the cessation of hostilities in Vietnam." London Times, June 26, 1962, p. 10, col. 4.

48 See International Law Comm'n, Draft Code of Offenses against the Peace and Secturity of Mankind, U.N. GeN. Ass. OFF. Rec. 9th Sess., Supp. No. 9 (A/2693) (1954) in 49 AMr. J. INT'x L. SUPp. 21 (1955) and SoHn, Basic Documeints of the UNITEd Nations 99 (1956); International Law Comm'n, Draft Declaration on Rights and Duties of States, U.N. GEN. Ass. OrF. Rec. 4th Sess., Supp. No. 10 (A/925) (1947), in 44 Axr. J. INT'L L. Supr. 13 (1950) and Some, op. cit. supra note 26; Charter of the Organization of AMarrican States art. 15, Dec. 13, 1951, [1951] 2 U.S.T. \& O.I.A. 2394, T.I.A.S. No. 2361, 119 U.N.T.S. 3 ; Thomas \& Thomas, Non-Intervention (1956). See also 1 Oprenhetar 293; Curtis, The Law of Hostile Military Expeditions as Applied by the United States, 8 AM. J. INT'L L. 1, 34 (1914); GarciaMora, International Law and the Law of Hostile Military Expeditions, 27 FordinM L. REv. 309 (1958); Lauterpacht, Revolutionary Propaganda by Government, 13 Transacr. Gror. Soc'y 143, 146 (1928).

49 The Vietminh might claim that North and South Vietnam together are one country, and that hostilities between the two sections are just civil strife and thus not banned by international law. But Professor Wright seems correct in saying "if such (armistice) lines have been long continued and widely recognized, as have those in Germany, Palestine, Kaslımir, Korea, Vietnam and the Straights of Formosa, they assume the character of international boundaries. Hostilities across them immediately constitute breaches of international peace. . . "Wright, International Law and Civil Strife, in 1959 Procejedngs AMrerican Soc'y INT'L L. 145, 151. 1 Oprenhem 258 lists North and South Vietnain as separate states. 
ritory to be used by their nationals or by anyone else, as a base of operations for such expeditions. ${ }^{50}$ The Vietminh have also violated this rule. International law forbids one state to direct subversive propaganda at another. ${ }^{51}$ If any part of the propaganda coming into Vietnam from North Vietnam emanates from the Vietw minh government, as is almost certain in a state where the radio and press are government operated, the Vietminh have violated this rule. ${ }^{52}$ Finally, there may be a norm of international law prohibiting terrorist activities and obligating states to repress such activities aimed at residents of other countries. ${ }^{53}$ If there is such a rnle, the Vietminh have violated it.

The United Nations Charter forbids member states to use force against the territorial integrity or political independence of any other state. ${ }^{54}$ Professor Wright has suggested that article 2, paragraph 4 and other provisions of the charter "prohibit only the threat or use of armed force or an armed attack. They cannot be constrned to include other hostile acts such as propaganda, infiltration or sub-

50 See Dispute of Honduras and Nicaragua against Salvador and Guatemala, 2 Ax. J. InT'x L. 838 (Cent. Am. Ct. Justice 1908); International Law Comm'n, Draft Code of Ofjenses against the Peace and Security of Mankind, supra note 48; International Law Comm'n, Draft Declaration on Rights and Duties of States, supra note 48; 1 OPPENHEn 292; Curtis, The Law of Hostile Military Expeditions as Applied by the United States, 8 Axr. J. INT'x I. 1 (1914); Lauterpacht, Revolutionary Activities by Private Persons Against Foreign States, 22 Aar. J. INT'L L. 105, 121 (1928).

61 See Acadeary of Scuences of the U.S.S.R., Institute of State and Law, InterNATIONAL LAw 405; Convention concerning the Use of Broadcasting in the Course of Peace, 186 I.N.T.S. 301, 7 Hudson, INTERNaTIONAL Legislation 409 (1936) (ratified by 23 countries as of Jan. 1, 1941; neither the U.S. nor the U.S.S.R. had then ratified); Condemnation of Propaganda against Peace, U.N. Gen. Ass. OfF. Rec. 5th Sess., Annexes vol. II, Agenda Item No. 69, at 7 (A/1490) (1950); Garcia-Mora, International Responsibility for Subversive Activities and Hostile Propaganda by Private Persons Against Foreign States, 35 Ind. L.J. 306 (1960); Lauterpacht, Revolutionary Propaganda by Governments, 13 Transact. GroT. Soc'Y 143 (1928) ; Preuss, International Responsibility for Hostile Propaganga Against Foreign States, 28 Axr. J. INT'L L. 649, 668 (1934); Whitton, The International Law of Propaganda, 72 ACAdÉame de Droit International, RecueIr des Cours 565, 583 (1948); Wright, The Crime of 'War-Mongering,' 42 Ax. J. INT'x L. 128 (1948). The Communist bloc, by internal legislation, has indicated agreement. See U.S.S.R. Peace Defense Act, March 12, 1951, 46 AMr. J. InT'2 I. SupP. 34 (1952). The supplement also contains similar acts of Albania (at 101), Bulgaria (at 102), Czechoslovakia (at 34), East Germany (at 99), Hungary (at 102), Outer Mongolia (at 104), Poland (at 103), and Rumama (at 104).

52 The authorities are in disagreement as to whether a state is responsible for subversive propagandizing by its private citizens. Garcia-Mora says a state is responsible for such propagandizing. Garcia-Mora, International Responsibility for Subversive Activities and Hostile Propaganda by Private Persons against Foreign States, 35 IND. L.J. 306, 335 (1960). Also indicating responsibility is the Convention concerning the Use of Broadcasting in the Cause of Peace, op. cit. supra note 51. The leading authorities finding no responsibility are Lauterpacht, Revolutionary Activities by Private Persons Against Foreign States, 22 Axr. J. INT'L L. 105, 126 (1928) ; Preuss, International Responsibility for Hostile Propaganda against Foreign States, 28 Axr. J. INT'L L. 649, 668 (1934).

53 See 1 OPPENHETar 292 n.5; Convention for the Prevention and Punishment of Terrorism, 7 IIUDSON, INTERnationai Legislation 862 (1937) (not entered into force as of Jan. 1, 1941, when only India had ratified), commented on in 19 BRIT. Yв. INT'L L. 214 (1938). Art. 2(6) of the Draft Code of Offenses against the Peace and Security of Mankind, supra note 48, prohibits "the undertaking or encouragement by the authorities of a State of terrorist activities in another State, or the toleration by the authorities of a State of organized activities calculated to carry out terrorist acts in another State."

¿4 U.N. Charter art. 2, para. 4. 
version." ${ }^{255}$ This suggestion must be rejected if the world is to have an effective law of non-aggression.

One of the major defects of the League of Nations Covenant and the KelloggBriand Pact was that in renouncing only "war" they left the door open for resort to hostilities under some other name. ${ }^{56}$ It was in order to escape this confusion, where "the God Mars operates, as it were, in mufti", lated the rule differently ${ }^{58}$ Subversion must be included in the definition of "force" if article 2, paragraph 4 is to have vitality. ${ }^{59}$ Professor Wright's earlier suggestion, which he has apparently discarded, reflects the correct rule: "[C]omplicity by ... a government in the infiltration of armed volunteers, guerrillas, or other armed forces in the territory of another state or across a recognized armistice or cease-fire line is presumed to be aggression." 60 The General Assembly, in its resolution on the Greek problem, called for the recoguition of such a rule.".

If North Vietnam, a nonmember of the United Nations, is subject to article 2, paragraph 4, the Vietminh have violated the charter. Article 2, paragraph 6 of the charter provides: "The Organization shall ensure that states which are not Members of the United Nations act in accordance with these Principles so far as may be necessary for the maintenance of international peace and security." Professor Kelsen interprets this clause as imposing on nonmembers the obligations of article 2, paragraph $4 .{ }^{62}$ Other authorities maintain that no legal obligations are imposed on nonmembers by the charter. ${ }^{63}$ Professor Kelsen appears to have the better of the argument. ${ }^{64}$ His position is strengthened by the General Assembly's action during the Greek crisis; the Assembly placed the obligations of article 2, paragraph 4 on the nonmember states of Albania and Bulgaria. ${ }^{65}$

In The S.S. "Lotus" the court said: "Now the first and foremost restriction

55 Wright, Subversive Intervention, 54 AN. J. INT'x L. 521,529 (1960).

56 Stone, Legat Controls of InternationaI ConfiIct 300 (1954); Waldock, The Regulation of the Use by Force by Individual States in International Law, 81 ACADÉMIE DE DROIT INTERNATIONAI, RECUEII DES COURS 455, 487 (1952).

57 Stone, Legal Controls of International Conzlict 311 (1954).

58 Id. at 314.

59 "The apparent cases of subversion are covered by a general definition based on art. 24." Röling, On Aggression, 2 NED. TyJdschrnFT vooR INT'L RECHT 167, 172 (1955). See Peace Through Deeds resolution, U.N. GEN. Ass. OFF. Rec. 5th Sess., Annexes vol. II, Agenda Item No. 69, at 7 (A/1490) (1950). (1959).

60 Wright, United States Intervention in the Lebanon, 53 AM. J. INT'L L. 112, 114-15

${ }^{61}$ See Threats to the Political Independence and Territorial Integrity of Greece, [19481949] YEARBOOK OF THE UNITED NaTTONS 238.

62 Kelsen, THe Law of the United Nations 108 (1951). See also Ross, Constitution OF THE UNITED NATIONS 33 (1950).

63 See Kunz, Revolutionary Creation of Norms in International Law, 41 Axs. J. INT'x L. 119 (1947).

64 As a matter of statutory construction, if the United Nations is to ensure that nonmembers act in a certain way, it can only be because nonmembers have an obligation so to act. As Kelsen points out, the purpose of the United Nations-the maintenance of world peace requires that the whole world be subject to the fundamental obligations imposed by the charter. KEISEN, supra note 62, at 106-08. Under art. 2, para. 6, the obligations of nonmembers exist only "so far as may be necessary for the maintenance of international peace and security." The obligation to refrain from the use of force, imposed by art. 2, para. 4, is a fundamental part of the United Nations system for the mamtenance of international peace and security, and would thus appear to apply to nonmembers.

65 See Threats to the Political Independence and Territorial Integrity of Greece, supra note 61 . 
imposed by international law upon a State is that-failing the existence of a permissive rule to the contrary it may not exercise its power in any form in the territory of another State." 86 This rule stems from the idea that the sovereignty of a state gives it the exclusive right to exercise the functions of a state within its boundaries. $^{67}$

It has been shown that the United States is exercising its power in many ways within Vietnam. Nevertheless, the United States cannot be said to have impinged on Vietnamese sovereignty if Vietnain has, in the exercise of its sovereignty, requested the United States to thus exercise its power. ${ }^{68}$ The American activities would then be justifiable aid, not illegal intervention.

The question raised by the Diem government's request that the United States aid in the Vietnamese struggle is whether this request brings the United States activities within the exception to the rule of The S.S. "Lotus." The issues involved are outlined in the leading work on the law of intervention:

In order that consent may be recognized as a valid basis for legality of intervention, the consent must be legal. To be legal it must be granted by the legal representative of the state. A consent by a government in time of civil conflict to an intervention on the part of another state to establish and maintain that government could lardly be called the consent of the state, for the very fact of civil war would show that the identity of the legal representative of the state was in doubt. 69

While authorities agree with this statement of the law, there is controversy centering around two points. First, what is the effect of a pre-existing treaty whereby one state gnarantees that it will assist the other if such assistance is needed? Second, when is there such a state of civil war as to call for invocation of the doctrine of nonintervention?

As to the first question, Lauterpacht writes: "A State that has guaranteed by treaty the form of government of another State ... has a right to intervene in case of change in the form of government ...." is not generally recognized." Hyde's view is that the legal situation is not altered "by reason of the fact that intervention occurs in pursuance of a treaty of guaranty .... . 72 The belief that a treaty can change the law of intervention is seemingly based on the proposition that a state may "undertake the obligation to retain a certain form of government ... . ${ }^{273}$ The opposing, and apparently preva-

68 Case of the S.S. "Lotus," P.C.I.J., ser. A, No. 10, p. 18 (1927), in 2 Hudson, Wornd COURT REPORTS 20 (1935).

67 The Island of Palmas, 2 U.N. Rep. Int'I Arb. Awards 829, 838 (1928), in Scotr, Hague CoURT REPORTS 83 (1928).

c8 See, e.g., Wright, The Prevention of Aggression, 50 Axr. J. INr't L. 514, 530 (1956).

60 Thomas \& Thomas, Non-Intervention 93-94 (1956) [hereinafter cited as Thomas \& Trouras]. This classical statement is accepted by the Communist camp, as illustrated by the statement in a recent text on international law which states: "From the principle of sovereignty and sovereign equality flows the impermissibility of intervention by one State in the internal affairs of another." Acadedry of ScIences of the U.S.S.R., Institute of STAte ANd Law, INTERNATIONAI LAW 134.

701 Oppenhenar 309. See also Brierty, Law of Nations 287-88 (4th ed. 1949).

711 OPPENHETS 309 n.1.

721 Hyde, International Law Chiefly as Interpreted and Appuised by the United STATES 253 (2d ed. 1945).

731 OPPENHEIS 309 n.1. This statement is made in Lauterpacht's Oppenheim to support the rule quoted in the text of this comment accompanying note 70 supra. But in the rule it is the promisor that is said to have a rigbt to intervene, while in the supporting statement the state having a right to intervene would be the promisee. This logical inconsistency casts doubt on the rule suggested by Lauterpacht. 
lent, belief is founded on the right of revolution, ${ }^{74}$ which is a cornerstone of the law of nonintervention. ${ }^{75}$ If there were a treaty between the United States and Vietnam giving the former some protectable interest in seeing that the latter did not change its form of government, that interest would appear to be outweighed by Vietnam's right to self-government. This consideration alone militates for the Hyde view. But even if one were to strike the balance in favor of the right to see that a certain form of governnent is retained, the United States-Vietnam Mutual Defense Treaty ${ }^{76}$ does not appear to grant such a riglit to the United States; it merely grants Vietnam a right to assistance, with no substantial rights given the United States in return. Thus, under neither Hyde's nor Lauterpacht's rationale is the United States position enhanced by this treaty.

\section{Professor Wright describes the next controversy thus:}

Some writers have taken the view that only if civil strife has been generally recognized as "belligerency," obhiging outside states to be "neutral," are such states forbidden to give military assistance to either faction, but where belligerency has not been recognized, and the situation is one merely of "insurgency," military aid may be given to the recognized government but not to the insurgents. The predominant opinion, however, follows the view ... that in respect to military intervention, the critical line is not recognition of belligerency, but the uncertainty of the outcome.77

Neither the recognition of belligerency test nor the uncertainty of outcome test appears to be satisfactory. The recognition test seems to be based, not on the right of revolution, but on a mechanistic application of the laws of war and neutrality to civil war. ${ }^{78}$ To say that states may legally help a beleaguered government so long as they do not recognize insurgents as belligerents is to say that so long as a revolt is small the strength of the world may be exerted against it; thus the right of revolution may be exercised only by the powerful. The substance of the right of revolution is further undermined by those authorities who hold that an outside state has no obligation to recognize belligerency, but may recognize or refuse to recognize in its discretion. ${ }^{79}$ By making recognition of belligerency "an act of

741 HXDE, op. cit. supra note 72, at 254. See also ACADEMYY oF SCIENCES OF THE U.S.S.R., InstrTute of State and Law, International Law 114, which urges "the recognition of each people's right to be inaster in its own country-that is, its unconditional right itself to decide its own social and political system and to determine its internal and foreign policy without any interference whatsoever by other States. ..."

75 Wright, Subversive Intervention, 54 AMr. J. INT'L L. 521, 529 (1960).

76 [1955] 3 U.S.T. \& O.I.A. 4672, T.I.A.S. No. 2623.

77 Wright, United States Intervention in the Lebanon, 53 AMr. J. INT'r I. 112, 122 (1959).

78 "Following recognition as a belligerent party, a situation is created akin to that existing when two independent governments are at war. The party struggling for power, as a result of its recognition as a belligerant party, acquires the rights and obhgations of a belligerent state." ACADEMY of ScIences of the U.S.S.R., Institute of State and LaW, International Law 120. Another possible justification for the test may be found in the felt need for stability in the international community.

791 Hack worte, Digest of International Law 319 (1940). See also Ross, A TeXTBook of International Law 123 (1947). Professor Pallieri has argued that, while most writers beheve there is no obligation to recognize belligerency, international practice shows no instance of a refusal to grant at least de facto recognition to belligerents. He points to the Spanish Civil War where, despite a refusal to formally recognize belligerency, neutral states in fact treated the insurgents as having the rights of belligerents. Pallieri, Quelques Aspects Jutridiques de la Non-Intervention en Espagne, 64 RevUE DE DROIT INT'L ET DE LECISLATION COMPAREe 285, 287-88, 308 (Brussels 1937). 
unfettered political discretion" 80 the law would in effect be abandoning the rule that states are free to choose their own form of government. The better view seems to be that "after the international requirements for the recognition of belligerency have been fulfilled, a duty of recognition of belligerency necessarily follows, and refusal of recognition is interference with the right of political self-determination of the people of a state, and therefore constitutes illegal intervention." 81

Applying either view of the recognition test, the United States interference in Vietnam is justified. The United States has not recognized the belligerency of the Viet Cong, nor does it appear to have such a duty. Lauterpacht lists the following as the conditions necesary to give insurgents the status of belligerents:
the existence of a civil war accompanied by a state of general hostilities; occupation and a measure of orderly administration of a substantial part of national territory by the insurgents; observance of the rules of warfare on the part of the insurgent forces acting under a responsible anthority; the practical necessity for third States to define their attitude to the civil war. 82

The Viet Cong do not observe the laws of warfare, and for this reason alone should be denied the right to recognition as belligerents. In addition they do not administer a substantial part of national territory; the most that can be said is that they prevent Vietnam from the orderly administration of a substantial part of the country.

A major shortcoming of Professor Wright's uncertainty of outcoine test is the uncertainty of the test. Professor Wright has provided no standards for ascertaming that the outcome of civil strife is "uncertain." This faihing puts the uncertaimty test in no better light than the discretionary recognition of belligerency test. Under Professor Wright's test, even if there is uncertainty as to the outcome of civil strife, only outside military assistance to the government is forbidden. ${ }^{83}$ The term "military assistance" is not defined; nor is the reason given for distinguishing between military and non-military assistance. This is an uncertainty of great relevance to the Vietnam question. For, while it is clear that, absent United States aid, the future of the Diem government would at best be uncertam, it is not clear whether the United States interference in Vietnam constitutes "military assistance." 84 "Military assistance" could have one of several meanings. It could mean any aid that would help the beleaguered government militarily. In Vietnam, all aid would fall into that category. It could mean sales or gifts of military equipment, munitions, and advice. The United States is giving such aid to the Diem

802 OPPENHEIM, INTERNATTONAL LAW $250 \mathrm{n} .2$ (7th ed. Lauterpacht 1952) [bereinafter cited as 2 OPPENHETar].

81 Thomas \& Thomas 220. See also 2 Oppenhen 249; Pallieri, supra note 79. The United States position that the recognition of a government is a purely political and thus discretionary question (see 39 DEP'T STATE BuLL. 385 (1958)), should be irrelevant to the question of recognition of belligerency. The differences between recognition of a government and recognition of belligerency are pointed out in Smith, Some Problems of the Spanish Civil War, 18 BRIT. YB. INT'x L. 17 (1937). See also The Prize Cases, 67 U.S. 635, 666 (1862).

822 OPPENhens 249. See also The Prize Cases, 67 U.S. 635, 666, 667 (1862); Pallieri, supra note 79, at 286 .

${ }^{83}$ The International Control Commission has characterized the United States activity as "military aid" and "factual military alliance." London Times, June 26, 1962, p. 10, col.4.

84 Under the recognition test, the problem of defining "military assistance" does not arise, since, once belligerency has been recognized, third states "can either becoine a party to the war or remain neutral, and in the latter case all the duties and rights of neutrality devolve upon them." 2 OPPENHEIMr 660. Neutrality imposes "the duty of abstaining from assisting either belligerent, whether actively or passively. ..." Id. at 659 . 
government. Finally, defining the term most narrowly, it could mean aid in the form of combat troops. It is not at all clear whether the United States assistance falls into this last category.

It is thus seen that under the recognition of belligerency test the United States interference in Vietnam is legal, since a state of belligerency does not exist in Vietnam; under the uncertainty of outcome test, the interference may be legal if only combative aid is forbidden, and would be illegal under other definitions of military aid if only a civil insurrection were involved. But there is another element present that removes any question of the legality, under general international law, of the Umited States actions. That element is the Vietminh subversive intervention in Vietnam.

Writers on the subject are agreed that "counter-intervention is permitted by general international law to terminate an illegal intervention and to prevent a situation illegal in origin from becoming effective .... ${ }^{185}$ This eminently sensible rule has two bases. That given by Hyde is that "any member of the family of nations is authorized to oppose so grave a violation of international law as the unwarranted interference with the political independence of one of their number." twentieth century context, the more meaningful basis of the rule is a result of the Cold War: "[A] failure to intervene [is] an acquiescence to intervention; whereas an equivalent intervention leads to a neutralization of the first intervention." 87 The practical objection to major power counter-intervention is that it can enmesh the major powers in direct armed conflict with each other. ${ }^{88}$ The answer to this objection is that to fail to counter-intervene is "to intervene (passively) on the side of one's enemy." 89

If the situation were only that the Vietminh have intervened in Vietnam, it would appear that the United States is fully justified in its response to the Diem call for counter-intervention. However, in Vietnam, as already noted, the Diem government faces a combination of internal insurgency and Vietminh subversive intervention. Professor Wright, who has been a leading proponent of nonintervention, has this to say about such a situation: ". . . a state victim of 'subversive intervention' can properly ask for aid from other states within its own territory, and other states can properly respond to such a request ...."90 It is true that counter-intervention in this case does more than neutralize the first intervention, since it also eliminates the indigenous insurgency. Nevertheless, the two rationales for allowing counter-intervention to terminate an illegal intervention appear equally applicable where the illegal intervention is supported by internal insurgency. Indeed, almost all illegal interventions are accompanied by some internal support. And in Vietnam it is impossible to separate the two, since the internal insurgency is caused or at least supported largely by Vietminh propaganda and terrorism. It has been suggested that "in view of the serious and common danger which threatens the peace and order of the nontotalitarian community of nations,

85 Thomas \& Thomas 407.

861 HYDE, op. cit. supra note 72, at 248.

87 Falk, American Intervention in Cuba and The Rule of Law, 22 Oно ST. L.J. 546, 567 (1961).

88 See, e.g., Bowett, Collective Self-Defense under the Charter of the United Nations, 32 BRIT. YB. INT'I L. 130, 157 (1955-1956).

89 Falk, The United States and the Doctrine of Nonintervention in the Internal Affairs of Independent States, 5 How. L.J. 163, 168 (1959).

90 Wright, United States Intervention in the Lebanton, 53 Ax. J. INT'工 L. 112, 123 (1959). 
any nation or group of nations may, under general international law, take action to uphold the law to prevent a state from being destroyed by totalitarian propaganda." ${ }^{01}$ Whether or not this last suggestion, based on an axiological rather than a positivist approach to international law, ${ }^{92}$ accurately represents the law, Professor Wright's formulation of the rules appears accurate; under it, the United States counter-intervention in Vietnam is legal..$^{93}$

C.

Having determined that the United States has violated no rule of general international law by its activities in Vietnam, it is still necessary to examine the United States legal position under the United Nations Charter. The charter, like general international law, forbids the intervention of one state in the affairs of another, but makes an exception in the case of an invitation by the state. ${ }^{94}$ It seems to follow that the charter allows counter-interventions where they are permitted by general international law..$^{95}$ Any right of counter-intervention under the charter, however, is greatly limited by the obligations to peaceably settle disputes that endanger international peace and security,$^{96}$ and to refrain from the use of force..$^{97}$ Thus, Thomas and Thomas say that counter-interventions are allowed so long as they do not involve the use or threat of force. ${ }^{98}$ Professor Wright argues that "the recognition in the Charter of the 'sovereign equality' of states clearly permits a state to use armed force in the territory of another state on the invitation of the latter . . . "99 However sound the latter approach may appear in special, tempo-

\section{Thomas \& Thomas 285.}

$92 I d$. at 283.

${ }^{93}$ It may be argued that the United States interference is pursuant to an illegal invitation, since the International Control Commission has held that South Vietnam, in receiving military aid fron the United States and in entering a "factual military alliance," with the United States, is violating articles 16, 17, and 19 of the Geneva Agreement. London Times, June 26, 1962, p. 10, col. 4. Cf. Harvard Law School Research in International Law, Draft Convention on the Law of Treaties, art. 22(c), 29 Axr. J. INT'L SUPp. 661-62 (1935): "If a State assumes by a treaty with another State an obligation which is in conflict with an obligation which it has assumed by an earker treaty with a third State, the obligation assumed by the earlier treaty takes priority over the obhigation assumed by the later treaty." There are two answers to this argument. First, it is not at all clear that South Vietnain was ever bound by the Geneva Agreements. See text accompanying notes 36,38 , and 46 supra. Second, North Vietnam's violations of the agreenients preceded large scale Umited States assistance (see Note from United Kingdom to U.S.S.R., June 14, 1962, as reported in London Times, supra), thus giving South Vietnam the right to cancel the agreements. 1 OPPENAEDM 947. South Vietnam's consistent denunciations of the agreements should be considered as a cancellation of them, if South Vietnam was in fact originally bound. See, e.g., President Ngo Dinh Diem's broadcast of July 16, 1955: "We are not bound in any way by these agreements signed against the will of the Vietnamese people." Ministry of Inforasation, The Problems of Reunification of Vietnam 30 (Republic of Vietnam 1958).

94 Article 2, para. 4 forbids the use or threat of force against the "territorial integrity or political independence of any state." Interference pursuant to invitation obviously is not precluded by this provision. See also the reference to self-determination in art. 1, para. 2 .

95 Thomias \& Thomas 408-09.

96 U.N. CaARTER art. 2, para. 3 ; art. 33.

07 U.N. Charter art. 2, para. 4.

98 Thomas \& Thomas 408-09.

99 Wright, Subversive Intervention, 54 Axr. J. IsT'x L. 521,529 (1960). But see Ross, Constitution of the UNITEd Nations 134 (1950): "[T]he Charter on certain points encroaches on wbat is traditionally associated with the sovereignty ideology. ..." 
rarily urgent situations, the application of such a rule in a situation such as exists in Vietnam would appear contrary to the ideal of collective security envisioned by the charter. ${ }^{100}$ While the use of force in the inviting state's territory does not violate that state's "territorial integrity or political independence," 101 it would appear to be "inconsistent with the Purposes of the United Nations"102 and, in today's divided world, would endanger "international peace and security." 103

If the United States is a party to a dispute in Vietnam and the dispute endangers international peace and security, it would appear at first glance to be obligated to follow the mandates of articles 33 and 37. Article 33 commands the "parties to any dispute, the continuance of which is likely to endanger the maintenance of international peace and security" to try peaceably to settle their dispute. Article 37 says that if the parties fail to settle the dispute under article 33, "they shall refer it to the Security Council." Kelsen states: "A 'dispute' exists if one party makes a claim against another party and the other party rejects the claim." 104 In Vietnam the United States and the Vietminh have accused each other of violating international law and have demanded a cessation of the alleged violations. Thus, the United States would seem to be a party to the Vietnamese dispute. Further, the dispute appears to endanger international peace and security. ${ }^{105}$ While the charter says that the parties to such a dispute shall attempt to settle it by the means enumerated in article 33 and, if these fail, they shall refer the dispute to the Security Council, there is, at this preliminary stage, no body, other than the putative parties, to determine that the states are $\mathrm{m}$ fact parties to a dispute and that the dispute endangers international peace and security. Thus, even thougli the application of objective standards leads to the conclusion that the United States lias an obligation, which it is ignoring, no such obligation exists unless the United States itself says it exists. ${ }^{100}$ Lacking such an admission by the United States, the American troops may, as long as they do not violate the proscription in the charter against the use of force, continue to help the Vietnamese until the United Nations has acted. It is doubtful whether any American statements to date constitute an admission that the United States is a party to any dispute.

It may be, however, that the American military activities in Vietnam violate

${ }^{100}$ See Wright, The Prevention of Aggression, 50 Anr. J. INT'L L. 514, 524 (1956); Staff of Senate Committee on Foreign Relations, Review of the United Nations Charter, S. Doc. No. 164, 83d Cong., 2d Sess. 119 (1955).

101 U.N. CHARTER art. 2, para. 4.

102 Ibid.

103 U.N. Charter art. 2, para. 3.

104 KEISEN, THE LAW OF THE UNITED NATIONS 360 (1951).

105 See text accompanying notes 2-10 supra. Professor Wright says:

[A] 'breach of the peace' in the sense of Article 39, in this writer's view, exists whenever bostilities occur between armed forces controlled by governments de facto or de jure, at opposite sides of an internationally recognized frontier. . . . A 'threat to the peace' in the sense of Article 39 occurs when, because of a declaration of war, of intervention, or of other hostile intent by the government of a state against another state, or because of the magnitude of civil strife within a state, there is immediate danger of a breach of international peace.

Wright, The Prevention of Aggression, 50 Awr. J. INr'工 L. 514, 524-25 (1956). A dispute coming within art. 39 would also come within arts. 33 and 37.

106 KEISEN, THE LAW OF THE UNITED NATIONS 376 (1951). While this interpretation of articles 33 and 37 may, at first glance, appear to render meamingless the duty of pacific settlement, articles 34,35 , and 36 fill the seeming gap by providing alternative routes for the dispute or situation to reach the Security Council. 
the charter's proscription of the use of force. This depends upon the definition of "force" and the answer is not clear. ${ }^{107}$ If "force" does not include providing a combatant government with traiming, equipment, air support, and tactical and strategic advice-in short, with all military necessities except combat troops-it will prove to be easy for a country to evade the charter's proscription of the use of force. The analysis applied to the question of whether "force" includes "subversion" suggests that the United States is using force in Vietnam. Assuming that this is the case, the only possible justification for such conduct is article 51 of the charter, which allows states to exercise "the inherent right of individual or collective selfdefense." There are two viewpoints as to this highly relevant aspect of article 51. One maintams that collective self-defense can be resorted to only where "first, ... each participating State has an individual right of self-defense, and, second, ... there exists an agreement between the participating States to exercise their rights collectively." ${ }^{108}$ This view does violence to the language of article 51 by obliterating any meaningful distinction between "individual" and "collective" selfdefense. Kelsen's interpretation, while perbaps leading to a more primitive approach, appears to be the reasonable one. He says: "Article 51 confers the right to use force not only upon the attacked state but on other states which unite with the attacked state in order to assist it in defense."100 Since it is clear that Vietnam may defend itself, it would appear at first glance that under Kelsen's view the United States actions are justifiable under article 51. However, article 51 requires that those who invoke it report their action to the Security Council. The rights under article 51 are emergency rights only; as soon as possible, the United Nations is supposed to assume the responsibility for protecting international peace and security. ${ }^{110}$ By failing to report to the Security Council, the United States has lost any justification that article 51 might have provided. Thus, assuming that the United States is using force in Vietnam, its activities appear to violate article 2, paragraph 4 of the charter.

\section{CONCLUSION}

After this case study of the law of intervention, we are in a position to ask whether the law is adequate and whether the United States is following a wise policy in Vietnam. The point that most clearly emerges is that the general law of intervention is inadequate. One is initially tempted to agree with Professor Ross, who says "it will be wisest to let the chapter on intervention disappear entirely from International Law, at any rate for the present. For here we have passed the limit of what has a reasonable chance of being respected as law." 111 The United States has manifested no concern over its possible violations of the law in Vietnam,

107 While scholars are fond of defining illegal "aggression" in terms of "force," they do not tell us what "force" means. See, e.g., Röling, On Aggression, 2 Ned. TrJDScarnrT voor INT'L ReCHT 167, 181 (1955); Wright, The Prevention of Aggression, 50 AM. J. INT'工 L. 514, 526 (1956).

108 Bowett, supra note 88, at 139-40.

109 Kelsen, Lintitations on Functions of the United Nations, 55 YALE L.J. 997,1008 (1946). See also Jessur, A MODERN LAw of NATIONS 164-66 (1948); Wright, United States Intervention in the Lebanon, 53 Axr. J. INT'L L. 112, 118 (1959).

110 See Jessup, A MOdERN LAW OF Nations 164-66 (1948).

111 Ross, A Text-Boox of International Law 185 (1947). It should be noted that Professor Ross takes the same position as to war. Id. at 185-86. 
nor have the Communist nations adhered to the law. ${ }^{112}$ Ross is thus accurate in describing intervention as "violence as part of the policy of states."113 In a world of conflicting values it is difficult for the law to command respect where shortrange interests obstruct the view of the long-range imperative for nations to live together.

The law of intervention lacks clarity; under it, each potential intervenor decides for itself whether interference is legal; it is capable of being twisted to justify or condemn, as the twister sees fit. So long as many governments depend for their very existence upon United States aid, Russia can give to United States granting and withholding of aid the label of "intervention." Equally, since Communism is a world revolutionary movement having at least some contact with any significant modern revolution, the United States can tag any revolution as a Communist intervention, justifying counter-intervention on its part. And Professor Falk creates a fiction when he says that counter-intervention leaves the "target state about where it would have been without either intervention." 114 For it is clear that in most cases there is a winning intervenor who will shape the target state to its own purposes.

Despite the failures of the law of intervention, it is given devout lip service by those who violate it. There are two possible explanations for the support that both East and West give, in principle but not in practice, to nonintervention. A cynic would say that this support stenis from one of the law's basic defects, its ability to be twisted to meet any purpose. According to this school, the law of intervention is nothing more than a tool of propaganda. If this is the case, it is a disservice to include nonintervention as a norm of international law. The optimist's view must also be considered, however. He would say that the almost universal support for a law of intervention stems at least from a desire for peace in a world where intervention leads to counter-intervention, which may lead to a disastrous war; at most it stems from a belief in the principle of self-determination.

But the law cannot work if it merely tries to put "an international lid on a national boiling pot."115 It must instead provide a solution; and the solution, if it is to work, must be fair to both sides in the Cold War as well as to the rest of the world.

Although we agree that the world is neither at peace nor at war, ${ }^{110}$ but is involved in a Cold War, ${ }^{117}$ or intermediacy, ${ }^{118}$ or status mixtus, ${ }^{110}$ we need not conclude that a solution is precluded. Indeed, contrary to Falk's suggestion, ${ }^{120}$ the

112 As Falk says, "[I]n the Cold War matrix law now operates only at the upper himits of interventionary conduct (force)." Falk, The United States and the Doctrine of Nonintervention in the Internal Affairs of Independent States, 5 How. L.J. 163, 173 (1959).

113 Ross, A TEXT-BOoK OF InTERnational LAw 185 (1947).

114 Falk, American Intervention in Cuba and The Rule of Law, 22 Owo Sr. L.J. 546, 567 (1961).

115 Jessup, A Modern Law of Natrons 160 (1943).

116 See McDougal, Peace and War: Factual Continuum with Multiple Legal Consequences, 49 AM. J. INT'L L. 63 (1955).

117 See Orfieid \& RE, Cases and Matertats on Internattonal Law 618 (1958).

118 See Jessup, Intermediacy, 23 Nordisk TrDsskrift for INT'L RET: Acta ScANdinavaA JURIS GENTTUM 16 (1953).

110 See Schwarzenberger, Jus Pacis Ac Belli?, 37 Am. J. INT'x L. 460 (1943).

120 "Some of the difficulty arises because there is no adequate vertical institution with compulsory jurisdiction to determine whether contested acts constitute 'interventions.' " Falk, American Intervention in Cuba and The Rule of Law, 22 O\#по Sт. L.J. 546, 567 (1961). 
solution may be found in an existing institution, the United Nations. The United States could aid ni a resolution of the definitional and political problems by referrimg disputes, such as that in Vietnam, to the United Nations. For the problems of definition must be worked out case by case, and to withhold a case from consideration only hinders the development of viable definitions. Reference of disputes to the United Nations would at least soften the impact of power politics. Finally, despite its institutional shortcomings, the United Nations presents a meaningful alternative which is to be preferred to the present relegation of nonintervention to the realm of politics. The United States, were it to bring the Vietnamese dispute to the United Nations, could continue its activities in Vietnam until the United Nations reached a solution. ${ }^{221}$ While the Security Council cannot be expected to reach a decision, the General Assembly can. ${ }^{122}$ It is not to be presuned that the General Assembly will fail to provide for action against the Vietminh. In Greece, ${ }^{123}$ in Hungary, and in the Suez Canal case ${ }^{224}$ the General Assembly did what it could against illegal interventions.

The United States is attenpting to strengthen the United Nations collective security system by subscribing to a bond issue; United States adherence to the collective security plan of chapter VI of the charter would be an immeasurably more effective contribution.

Brian K. Landsberg

121 See Jessup, A Modern Law of Nations 164-66 (1948); Kexsen, The Law of the UNITED NATTONS 801 (1951); Waldock, The Regulation of the Use of Force by Individual States in International Law, 81 ACAdÉMIE de Drott Internationar, RecueIr des Cours 455, 488 (1952).

122 See Wright, The Prevention of Aggression, 50 Aar. J. InT'工 L. 514, 523 (1956) ; Bowett, Collective Self-Defense under the Charter of the United Nations, 32 BRIT. YB. INT'工 L. 130, 139 (1955-1956). Staff of the Senate Committee on Foreign Relations, Review of the United Nations Charter, S. Doc. No. 164, 83d Cong., 2d Sess. 139-45 (1955), summarizes Security Council and General Assembly handling of major disputes and situations from 1946 to 1954.

${ }^{123}$ See Howard, The General Assembly and the Probem of Greece, 17 Dep't State Buld. 1097 (1947); Threats to the Political Independence and Territorial Integrity of Greece, [19481949] YEARBOOR OF THE UNTTED NATIONS 238.

124 See Wright, Intervention, 1956, 51 Awr. J. INr'x L. 257 (1957). 